OPEN ACCESS

Edited by:

Taylor Maavara,

Yale University, United States

Reviewed by:

Fernando Mayer Pelicice, Federal University of Tocantins, Brazil Ana Cristina Petry, Federal University of Rio de Janeiro,

Brazil

*Correspondence:

A. Christine Swanson

a.christine.swanson@gmail.com

Specialty section:

This article was submitted to

Freshwater Science,

a section of the journal

Frontiers in Environmental Science

Received: 04 February 2021

Accepted: 06 April 2021

Published: 29 April 2021

Citation:

Swanson AC and Bohlman S (2021) Cumulative Impacts of Land

Cover Change and Dams on the Land-Water Interface of the Tocantins River.

Front. Environ. Sci. 9:662904. doi: 10.3389/fenvs.2021.662904

\section{Cumulative Impacts of Land Cover Change and Dams on the Land-Water Interface of the Tocantins River}

\author{
A. Christine Swanson* and Stephanie Bohlman \\ School of Forest, Fisheries, and Geomatics Sciences, University of Florida, Gainesville, FL, United States
}

Riparian vegetation performs important ecosystems services, improving water quality, mitigating erosion, and maintaining regional plant and animal biodiversity. Regular annual flooding maintains riparian forests through an intermediate disturbance regime. In response, seasonally flooded vegetation has developed adaptations for seed dispersal and gas transfer to survive and reproduce while undergoing periods of flooding. In the Amazon, a dam building boom threatens the integrity of riparian vegetation by moving riparian corridors into dry-adapted ecosystems and reducing downstream flooding of riparian areas. Additionally, the region is undergoing intense development pressure resulting in the conversion of native riparian vegetation into agriculture. In this study, we measure how the installation of six large dams on the Tocantins River, coupled with land cover change from native forest and savanna to cattle pasture, has changed the land-water interface of this region. Using land cover data provided by MapBiomas, we quantified land cover change from 1985 to 2018 and measured changes in the riparian areas of the still free-flowing areas of the Tocantins River, riparian areas surrounding reservoirs, and in-stream vegetation dynamics. We found that deforestation in the riparian areas of the Tocantins River downstream of the dams is occurring at a higher rate than deforestation in the watershed. Additionally, reservoir filling resulted in creating hundreds of square kilometers of new riparian areas, pushing the riparian zone away from forest-dominated ecosystems into savanna-dominated areas. The quantity of in-stream vegetation throughout the study was dynamic and initially increased after damming before declining for the last decade of the study. Changes to native land cover in riparian areas of the Tocantins River threaten the integrity of ecosystem services provided by riparian vegetation and are likely to lead to further degradation of these areas.

Keywords: land cover change (LCC), hydroelectric dams and reservoirs, Cerrado (Brazil), deforestation, pasture

\section{INTRODUCTION}

Riparian corridors are important for protecting river ecosystems. Ecosystem services performed by these areas include improving water quality through reducing siltation and agrochemical contamination (Newbold et al., 2010; Rieger et al., 2014), decreasing stream flow velocity and sediment transport (Keesstra et al., 2012), and protecting rivers from erosion (Wynn et al., 2004). 
In addition to regulating water quality and quantity (de Souza et al., 2013; Helfenstein and Kienast, 2014) and groundwater recharge (Bruijnzeel, 2004), riparian forests also maintain regional biodiversity of both plant and animal species (Naiman et al., 1993; Surasinghe and Baldwin, 2015) and are important for food security of riparian communities who use these nutrient rich areas for subsistence agriculture (Hiraoka, 1985; Laufer et al., 2020).

Riparian forests are shaped by their interaction with river ecosystems. Regular annual flooding maintains riparian forests (Junk et al., 1989). Trees in riparian forests that undergo annual flooding events have developed myriad adaptations to survive and reproduce in response to regular, long-term flooding (Parolin and Wittmann, 2010; Parolin, 2012). For instance, many trees reach peak fruiting during high flooding and for many species, seeds are dispersed by water (hydrochory) or fish (ichthyochory) (Kubitzki and Ziburski, 1994; Anderson et al., 2009). Regularly flooded trees also have morphological adaptations to survive prolonged flooding, including the formation exaggerated pores on stems to increase oxygen available to roots during periods of inundation (hypertrophy of lenticels), formation of adventitious roots, and development of soft tissues with air channels (aerenchyma) (De Simone et al., 2002; Parolin et al., 2004). The flooding depth gradient across riparian forests also allows for the existence of diverse species with different flood tolerances throughout the floodplain (Wittmann et al., 2008; Budke et al., 2010).

Given the strong effects of river flooding on forested riparian ecosystems, the alteration of rivers by dams has effects on both river hydrology and ecology as well on riparian forest structure and function. Hydrologic alterations can lead to tree mortality both upstream and downstream of dams (Nilsson and Berggren, 2000; Assahira et al., 2017; Resende et al., 2019). Changes in the flooding regime can also affect growth patterns of riparian trees (Resende et al., 2020) and lead to demographic changes as younger trees are unable to establish if the floodplain gets drier as a result of damming (Nilsson and Dynesius, 1994; Thomas, 1996). Over time, the composition of riparian forests that no longer regularly flood as a result of damming may come to resemble that of upland forests (Thomas, 1996; Rocha et al., 2019).

Impacts of dams on riparian forest are different between the reservoir and downstream areas. Reservoir creation alters the location of riparian areas, often pushing them into a new and different vegetation type than what bordered the free-flowing river. These new riparian vegetation types are often in dry-adapted ecosystems and may not perform the same ecosystem function as the original riparian vegetation (Nilsson and Berggren, 2000; Yang et al., 2018). Downstream of the dam, riparian forests may be impacted by changed river and floodplain hydrology. For instance, decreases in sediment transport downstream of a dam can lead to reduced regeneration for some species (Mallik and Richardson, 2009) or limit the range of wetland-dependent species (Alldredge and Moore, 2014). In the long term, these disruptions may lead to altered species composition and shifts in vegetation and land cover types in the riparian zone. Dam-induced changes, such as decreased water flow, in river hydrology can also increase in-stream vegetation on sandbars no longer subjected to regular flooding (Choi et al., 2005; Woo et al., 2010). These riparian forest changes may be heightened by two additional factors: cumulative impacts of multiple dams on the same river and concurrent land use changes as regions with dams undergo economic development.

The Amazon basin has some of the most extensive and species rich riparian and floodplain systems in the world (Junk, 2010; Wittmann et al., 2010). These forests are socially and ecologically important for their role in preserving fish biodiversity and maintaining fisheries, providing food and shelter to many species during high water periods (Lobón-Cerviá et al., 2015; Arantes et al., 2018). However, these forests may be threatened by extensive damming throughout the Amazon region (Lees et al., 2016). The dam building boom in the Amazon may have significant and cumulative impacts on riparian forest composition and function (da Rocha et al., 2019), yet relatively few studies have examined the impacts of dams in this region. Most studies focus at local scales (0.1-10 ha; e.g., Ferreira et al., 2013; de Lobo et al., 2019) or on effects of a single dam (e.g.,Assahira et al., 2017; da Rocha et al., 2019; de Lobo et al., 2019). However, installation of additional dams is likely to lead to cumulative impacts on rivers both locally and at the scale of whole river basins.

Dams are not the only threat to riparian forests-land cover change also imperils riparian ecosystems (Fernández et al., 2014). Natural vegetation has a role in regulating processes such as sediment transport (Keesstra et al., 2012) and erosion (Wynn et al., 2004), which impact channel morphology and affect regional biodiversity (Naiman et al., 1993). Despite the relationship between forest cover and riparian ecosystem functioning, few studies have quantified land cover change in riparian ecosystems globally (Zomer et al., 2001 in Europe; Jones et al., 2010 in the United States; Clerici et al., 2014 in Nepal) with no studies in the tropics. Land cover change in riparian forests may be context dependent and currently lower in areas where there has already been historic land cover change (Todd and Elmore, 1997) and higher in areas that are undergoing economic development (Clerici et al., 2014). These differences in land cover change may be reflective of different management or development priorities, and in some cases, may be the result of natural disturbance (Zomer et al., 2001).

Most countries recognize the importance of riparian forests and have made laws to protect them. Laws often include provisions to limit riparian forest removal within a buffer zone and/or to restore degraded or deforested riparian areas. In Brazil, the importance of riparian vegetation is recognized and codified through their forest code. Established in 1965, the forest code (Law 4771/65) requires $500 \mathrm{~m}$ buffers around rivers greater than $600 \mathrm{~m}$ wide where vegetation cannot be altered. If the buffer was destroyed or altered for any reason, it had to be replanted using native vegetation (Joly, 2010). The Brazilian forest code was revised in 2012 and the protections of riparian buffers were weakened, allowing removal of native vegetation for some economic activities (Covre et al., 2015). These changes to the Brazilian forest code have been widely criticized (da Silva et al., 2017; Biggs et al., 2019; Valera et al., 2019) and negatively impact 
both riparian vegetation and species that are dependent on this vegetation (Ledo and Colli, 2016; da Silva et al., 2017).

Despite their importance, riparian areas also get incomplete legal consideration in environmental impact assessments (EIA) which are required for large hydroelectric dams built in Brazil and other Amazonian countries. With respect to dam impacts to riparian areas, these EIA quantify deforestation expected from reservoir creation, but generally do not estimate expected changes to riparian forest outside of the reservoirs (Cochrane et al., 2017; Ritter et al., 2017). Accounting for alterations to riparian areas beyond deforestation resulting from reservoir creation is important for mitigating impacts of dams to riparian ecosystems and restoring productive riparian zones.

Given the importance of riparian forests for ecosystem services, ecology, biodiversity, and food security, understanding the impacts of dams and land cover change on these systems is essential. In this study, we investigated how vegetation cover in the land-water interface of the Tocantins River, the most dammed river in the Amazon region, changed from 1985 to 2018. We defined riparian areas broadly as those lands bordering rivers and lakes (National Research Council, 2002). Our objectives were to quantify land cover change and deforestation in (1) lotic (free-flowing portions of the river downstream of dams) and (2) lentic (areas that are now reservoirs after damming) portions of the river and to compare land cover change in these two zones to land conversion (3) from reservoir creation and (4) across the Tocantins landscape, combining riparian areas fronting lotic and lentic environments. Our final objective was to (5) measure changes in alluvial (in-stream) vegetation within the lotic portions of the river before and after damming. The outcome of this study will help us understand how land cover is changing within the riparian zone of the Tocantins River and how these changes are different for riparian areas along lotic and lentic habitats.

\section{MATERIALS AND METHODS}

\section{Study Site}

We conducted this study along a stretch of the Tocantins River that runs from the south of Lavrinhas in Goiás, where it meets a major tributary, north to to the confluence of the Tocantins with the Araguaia River (Figure 1). We chose the Tocantins River because it has recently experienced land cover change due to both extensive damming and conversion of natural lands to agriculture. The river runs from south to north with its headwaters in the state of Goiás and drains into the Atlantic Ocean near the city of Belém in the state of Pará. The Tocantins River has a total drainage area of $767,000 \mathrm{~km}^{2}$ with a mean annual discharge of approximately $11,000 \mathrm{~m}^{3} / \mathrm{s}$ (Costa et al., 2003).

Tocantins is the youngest state in Brazil, formed in 1988. As a result, the Tocantins watershed has undergone extensive development in recent decades. Population density increased from 2.66 inhabitants $/ \mathrm{km}^{2}$ in 1980 to 5.73 inhabitants $/ \mathrm{km}^{2}$ in 2020 (IBGE, 2020). The Belém-Brasília Highway (BR-153), which runs through Tocantins, acts as a regional development corridor (de Oliveira, 2015). Native vegetation throughout the region has been converted to pasture and soy monoculture (Treuhaft et al., 2009). The river is also the most dammed river in the Amazon region, with seven large dams (>30 MW) from its headwaters to its mouth and an additional two large dams planned for future development (Akama, 2017). The study region includes stretches of river downstream of six of the seven large dams (Serra da Mesa, Cana Brava, São Salvador, Peixe Angical, Lajeado, and Estreito; Figure 1) and reservoirs of those same six large dams.

The Tocantins River runs through the Cerrado biome, one of the world's biodiversity hotspots (Myers et al., 2000). Cerrado ranges from open grassland to nearly closed canopy forest. Canopy trees in the Cerrado range from 12 to $15 \mathrm{~m}$ in height, but the most prominent form of Cerrado has a stunted canopy (2$8 \mathrm{~m}$ tall) interspersed with large shrubs and grassy groundcover (Ratter et al., 1997). Cerrado vegetation is generally dry-adapted and drought tolerant and therefore not naturally the dominant vegetation type in riparian areas in the Tocantins. Surrounding the river, Cerrado transitions into riparian forests (matas cilliares; Ribeiro and Walter, 1998). Around small streams and tributaries, the riparian vegetation is gallery forest, and alluvial forests form within the stream bed (Ratter et al., 1997; Oliveira-Filho and Ratter, 2002). Approximately 13\% of the Tocantins watershed is considered protected land, the lowest of any major Amazonian watershed (Trancoso et al., 2009).

\section{Measuring Land Cover Change}

To understand how land cover changes may be different in different portions of this highly dammed system, we divided the land-water interface of the main channel of the Tocantins River into three separate regions: (1) the lotic zone, defined as portions of the river between the current reservoirs; (2) the lentic zone, defined as portions of the river that became a reservoir; and (3) the alluvial zone, defined as areas within the river channel (Figure 2). We examined land cover change in these zones in three land cover types: forest, savanna (Cerrado), and pasture. We selected pasture to represent agriculture because it was the dominant agricultural type in our dataset, accounting for approximately $99 \%$ of agricultural land in the region. To compare land cover change in the riparian area to areas away from the riparian zone in the lotic zone, we measured land cover type and deforestation rates in three locations for: (1) a $500 \mathrm{~m}$ buffer defined as riparian area of permanent protection by the Brazilian forest code, (2) a 500-1,000 m buffer beyond the riparian area of permanent protection, and (3) the Tocantins River watershed through the confluence with the Araguaia. For the lentic zone, we quantified forest loss in the $500 \mathrm{~m}$ riparian area of permanent protection. We compared the land cover composition in the lentic zone before reservoir creation, when the riparian area of permanent protection bordered a free-flowing river, to after reservoir creation, when this area bordered a standing lake. We quantified total areal coverage of forest and savanna lost to reservoir creation (where deforestation rates are near 100\% due to inundation from the reservoir) and compared it to the amount of forest and savanna loss from other sources (shifting of the riparian zone after reservoir creation, land cover change in the riparian area of the lotic zone). We quantified alluvial forest 

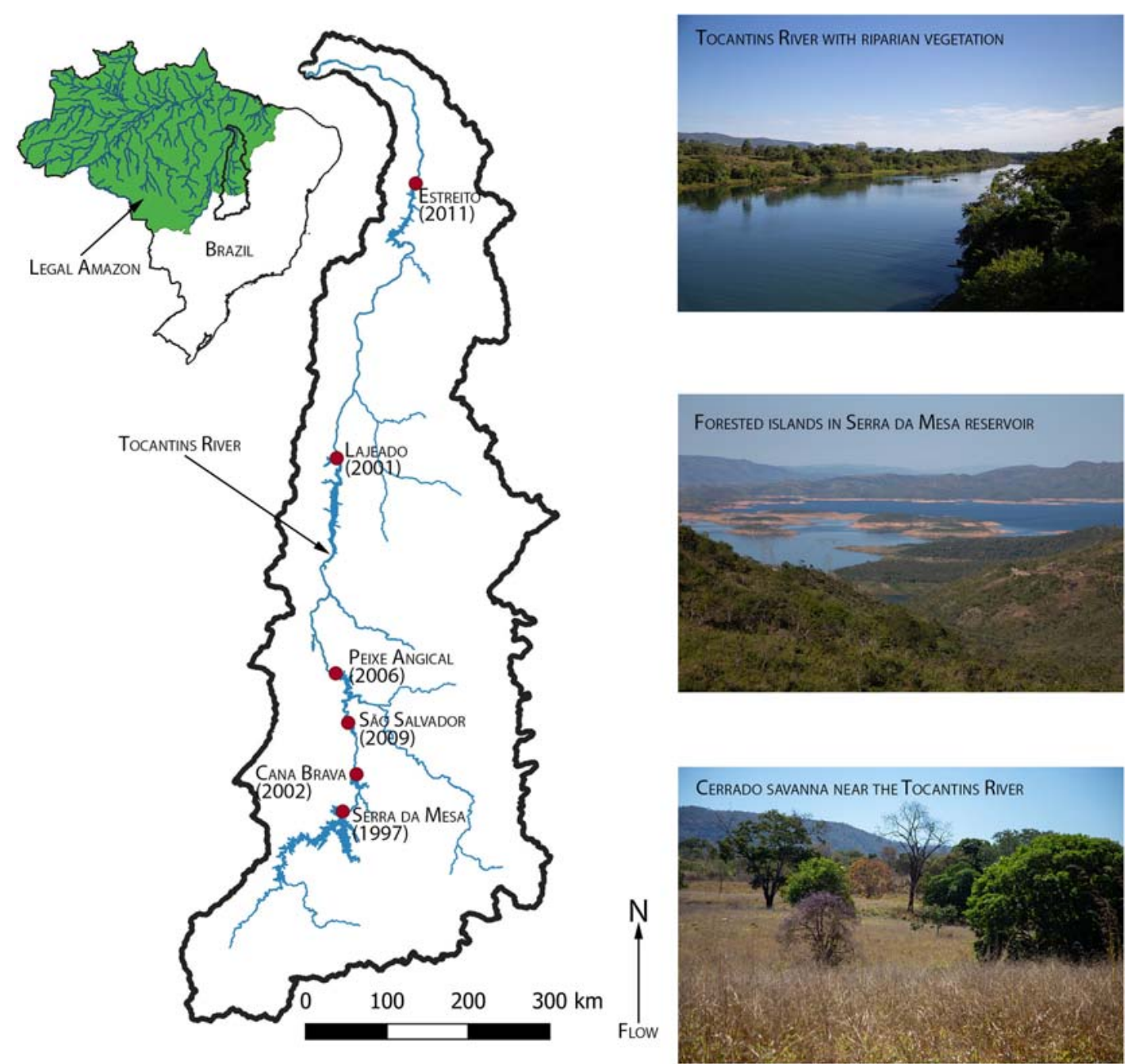

FIGURE 1 | Map of the Tocantins River watershed from the headwaters in Goiás to the confluence with the Araguaia River in Maranhão. The green area in the inset map of Brazil indicates the Legal Amazon. Inset images show examples of riparian vegetation, a reservoir, and Cerrado (savanna) on or near the Tocantins River.

cover only in the portions of the river that were lotic for the entire study period.

We used shapefiles from Brazil's Agência Nacional das Águas to define the boundaries of the lotic portions of the river and the reservoirs. We digitized the pre-dam river within the reservoirs based on historic satellite imagery using Google Earth Pro. Using QGIS v. 3.14, we created a $500 \mathrm{~m}$ buffer around the different portions of the river. We also created a 1,000 $\mathrm{m}$ buffer around the lotic river areas, then subtracted the $500 \mathrm{~m}$ buffer from this region to get a 500-1,000 $\mathrm{m}$ buffer. In both these buffer spaces, we removed the river or reservoir boundaries so that we were only measuring the vegetation.

We used the MapBiomas v. 4.1 land cover data (Souza et al., 2020) to quantify percent forest, savanna, and pasture cover in the buffers and reservoir areas before and after the reservoirs were filled. The MapBiomas project derived land cover annually from 1985 to 2018 from Landsat imagery at a $30 \mathrm{~m} \times 30 \mathrm{~m}$ pixel size (Souza et al., 2020). Land cover percentages and land cover conversion rates were calculated in $\mathrm{R}$ ( $\mathrm{R}$ Core Team, 2020), and code as well as accompanying data are available at DOI 10.5281/zenodo.448841 and 10.5281/zenodo.462008, respectively. We used Puyravaud's equation (Puyravaud, 2003) to quantify land cover conversion rates, where $r$ is the rate of land cover change and $t_{1}$ and $t_{2}$ were the first and last year of the study, respectively. $A_{1}$ is the total area in the first year and $A_{2}$ is the total area in the last year.

$$
r=\frac{1}{t_{1}-t_{2}} * \ln \left(\frac{A_{1}}{A_{2}}\right)
$$

\section{RESULTS}

\section{Land Cover Conversion in the Lotic Zone}

Over the 34-year study period, both savanna and forest in the riparian zone were converted to pasture at a nearly linear rate surrounding the lotic areas of the river that are 

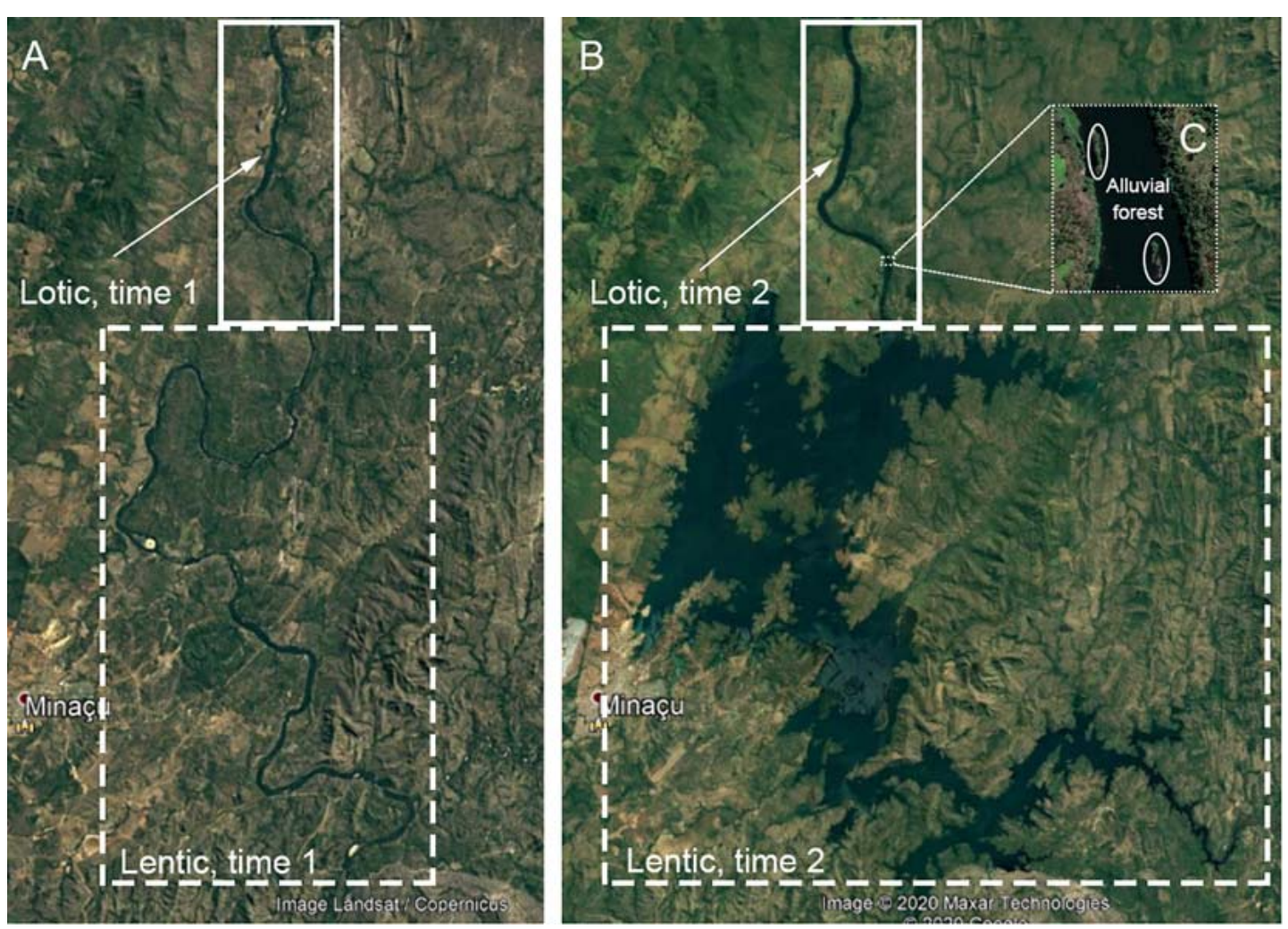

FIGURE 2 | Satellite imagery of the region surrounding the Cana Brava dam (installed 2002) near the city of Minaçu, Brazil showing (A) before the dam (1998), (B) after the dam (2020), and (C) close-up of alluvial vegetation within the river (2020). The regions in the solid rectangles represent the lotic zones of the river-areas that remained free-flowing throughout the study. The dashed rectangles represent the lentic zones of the river-areas that became dammed during the study. The dotted rectangle shows the alluvial forest found within the lotic portion of the river.

currently free-flowing (Figure 3). In the 0-500 m buffer, forest declined at an annual rate of $0.85 \%$ while savanna declined by $0.96 \%$ annually. Pasture increased at an annual rate of $2.60 \%$ (Figure 3A). There was a total loss of $108.17 \mathrm{~km}^{2}$ of forest and $69.31 \mathrm{~km}^{2}$ of savanna during the study period.

The area 500-1,000 $\mathrm{m}$ from the lotic portions of the river has more savanna and less forest than the area $0-500 \mathrm{~m}$ from the river (Figure 3B), demonstrating that the near shore environments of free-flowing rivers are important in supporting forest in this savanna-dominated landscape. In the area 500-1,000 $\mathrm{m}$ from the lotic portions of the river, there was a similar linear decline of forest (1.21\% annually) and savanna (1.27\% annually) and linear increase of pasture (3.13\% annually; Figure 3B). Savanna was initially the dominant land cover in this region, but it was overtaken by pasture in 2015 .

The watershed as a whole (excluding the $500 \mathrm{~m}$ riparian buffer; Figure 1) was dominated by savanna throughout the study (Supplementary Figure 1). By the end of the study, savanna and pasture were almost co-dominant, with savanna covering $35 \%$ of the watershed and pasture covering $30 \%$. Annual deforestation rates of both forest $(0.68 \%)$ and savanna $(0.78 \%)$ were lower in the watershed than in the riparian buffer while pasture also grew at a lower rate $(1.70 \%)$ in the watershed than in the riparian zone.

\section{Land Cover Conversion in the Lentic Zone}

The creation of reservoirs resulted in expanding the area considered riparian zone in this region (Figure 4). All reservoirs had at least double the riparian area that previously bordered the stretch of free-flowing river lost to the reservoir. The Serra da Mesa reservoir created $735.10 \mathrm{~km}^{2}$ of new riparian area, an increase of 339\%. Even the smallest reservoir, São Salvador, had a $136 \%$ increase in riparian area, growing from $38.56 \mathrm{~km}^{2}$ before the dam to $91.07 \mathrm{~km}^{2}$ after the dam.

The new riparian zone created by the reservoirs also had a different vegetation composition compared to the riparian area that once bordered the corresponding stretches of freeflowing river (Figure 5). All the stretches of river converted to reservoir were dominated by forest immediately before damming except the stretch of river that became the Lajeado reservoir, which had nearly equal cover of forest (37.2\%) and savanna (41.0\%). After damming, each newly created lentic zone had lower forest cover in the reservoir riparian zone compared to the previous free-flowing river riparian zone (Figure 5). The Peixe Angical reservoir area, for example, had $45.5 \%$ forest cover pre-damming. That amount dropped to only $16.8 \%$ after the reservoir was installed. Except for Lajeado, all riparian areas bordering reservoirs had a greater savanna cover than 

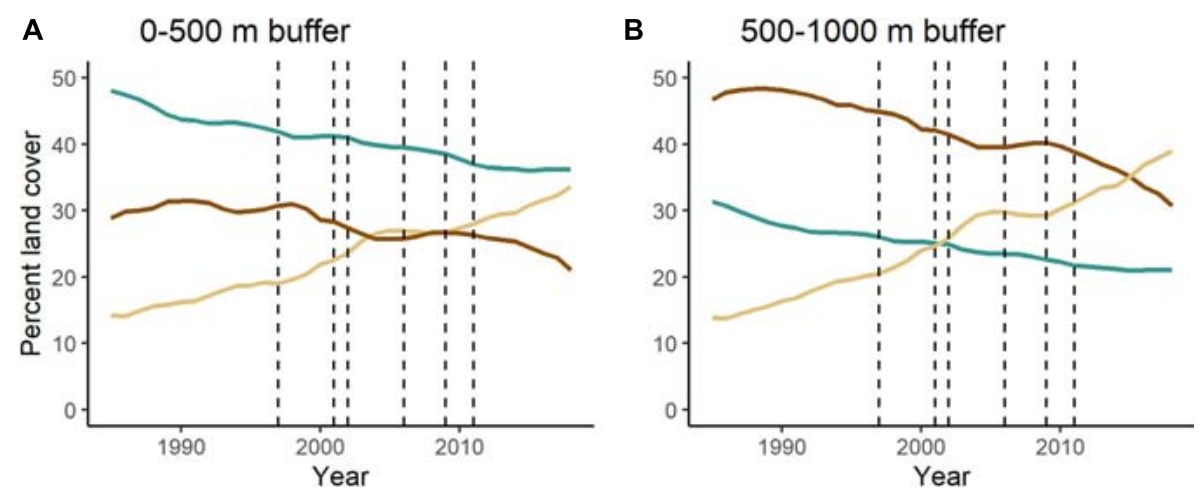

FIGURE 3 | Changes in composition of forest, savanna, and pasture in the (A) 0-500 m and (B) 500-1,000 m buffers surrounding the lotic portions of the Tocantins River. Dashed lines indicate years when a dam became operational (in order: Serra da Mesa, Lajeado, Cana Brava, Peixe Angical, São Salvador, Estreito). This analysis is restricted to portions of the river that are currently free-flowing and excludes any portion that eventually became a reservoir. Supplementary Figure $\mathbf{1}$ shows changes in composition of forest, savanna, and pasture across the watershed.

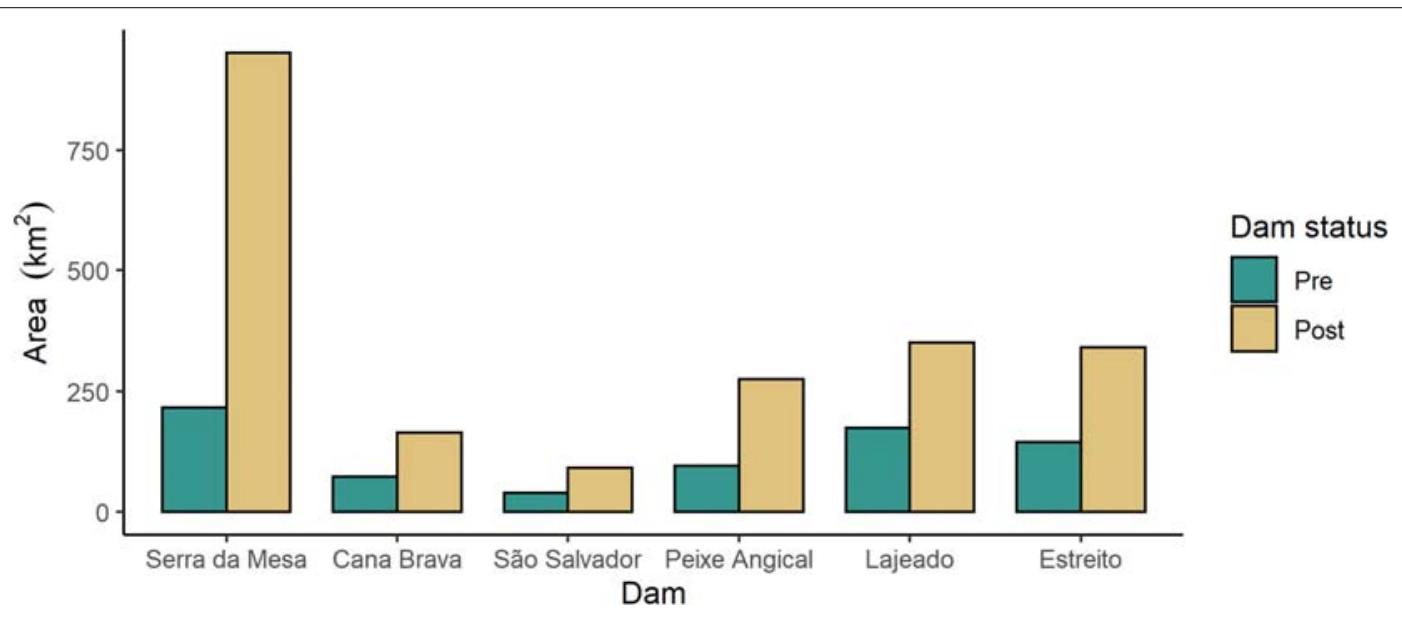

FIGURE 4 | Total area of the riparian buffer (0-500 m) in the stretches of river that are currently dammed, pre-dam (green; when the river was free-flowing) and post-dam (beige; where the river is now a reservoir). Dams are ordered by position on the river from upstream to downstream (left to right).

the riparian areas surrounding the corresponding free-flowing river. In fact, savanna became the dominant vegetation in the riparian zone surrounding all the reservoirs after damming, except for the Cana Brava reservoir riparian zone, which was still dominated by forest (46.8\% forest, $31.9 \%$ savanna). Even in the Lajeado area, which was not dominated by forest in either period, the proportion of forest dropped after the reservoir was opened (37.2\% dropping to $15.4 \%)$. For the Lajeado and Serra da Mesa reservoirs, pasture cover in the riparian zone increased immediately after damming. In the Serra da Mesa riparian zone, pasture increased from $9.8 \%$ before the dam to $35.1 \%$ after the dam, while in the Lajeado riparian zone, pasture increased from $11.7 \%$ before damming to $25.4 \%$ immediately after damming.

\section{Reservoir Creation}

Reservoir filling resulted in the loss of forest, savanna, and pasture for all six dams (Figure 6). Serra da Mesa, which has the largest reservoir, deforested $846.04 \mathrm{~km}^{2}$ of natural land cover, more than double the area of any other single dam and an area larger than the total forest and savanna lost from the creation of all other reservoirs combined $\left(812.47 \mathrm{~km}^{2}\right)$. The dominant land cover inundated by the reservoir varied, with forest loss being the greatest for the Serra da Mesa, Cana Brava, and Estreito dams; savanna the majority land cover being lost to the Peixe Angical and Lajeado reservoirs and pasture being the dominant land cover lost to the São Salvador dam (Figure 6). Despite all dams except Serra da Mesa being labeled as run-of-river and supposedly having lower impacts on hydrology and riparian ecosystems, the filling of every reservoir resulted in complete loss of the original riparian vegetation (Figure 6). Serra da Mesa, the largest reservoir by far (Figure 4), had the lowest percent loss of riparian forest $(31 \%)$. The other five reservoirs had a higher proportion of forest loss within the riparian zone, ranging from $48 \%$ to $88 \%$. Except for the Estreito dam, the percent of savanna lost that was in the riparian buffer was lower than the percent of forest lost within the riparian buffer. In Cana Brava, São Salvador, and Estreito, more than half of the savanna lost to reservoir creation occurred in the riparian area. 

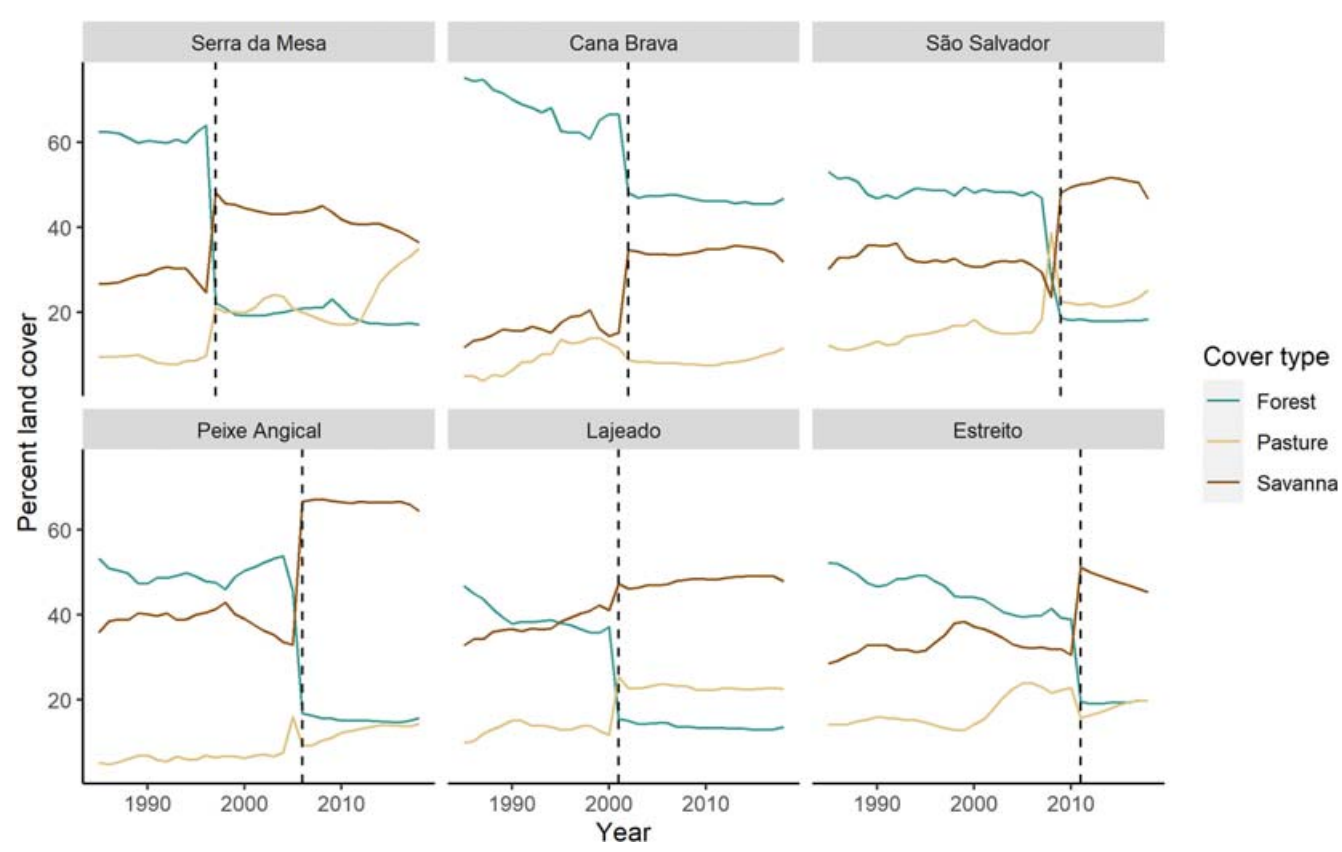

FIGURE 5 | Changes in composition of forest, savanna, and pasture in the 0-500 $\mathrm{m}$ riparian buffers surrounding the lentic portions of the river. The dashed line indicates when each dam opened. Lines to the left of the dashed lined indicate the buffer surrounding the pre-dam free-flowing river and those to the right of the dashed line indicate the buffer surrounding the post-dam lentic reservoir. Dams are ordered by position on the river from upstream to downstream (left to right, top to bottom).

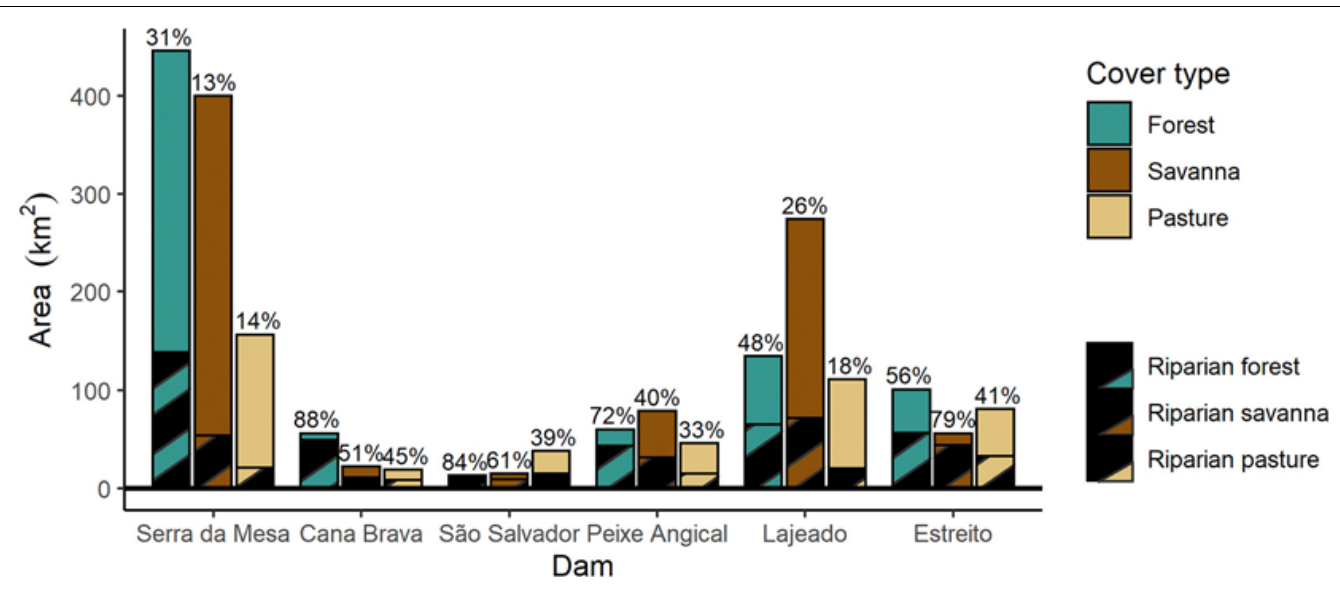

FIGURE 6 | Total loss in area $\left(\mathrm{km}^{2}\right)$ of forest, savanna, and pasture cover after the filling of each reservoir. The hatched area represents riparian forest in the 0-500 $\mathrm{m}$ buffer around the river before damming. Numbers are the percent of deforested area accounted for by the riparian buffer for each land cover class. Dams are ordered by position on the river from upstream to downstream (left to right).

The total amount of deforestation from reservoir creation, which is almost always the only land cover change accounted for in environmental impact statements, was $1,938.93 \mathrm{~km}^{2}$. However, reservoir filling moved riparian environments, creating a total of $2,176.67 \mathrm{~km}^{2}$ new riparian habitat, an area $112 \%$ the size of all the vegetated reservoir area across the landscape. Furthermore, another $926.36 \mathrm{~km}^{2}$ of riparian forest in lotic areas downstream of dams will most likely be impacted by hydrologic changes from dam operations.

\section{Land Cover Change Across the Tocantins Landscape}

When examining the riparian zone of the Tocantins River landscape (combining lotic and lentic environments), we see a large shift in dominant land cover from forest to savanna and pasture over the 34-year study (Figure 7). Although total area of forest cover remained relatively steady over time $\left(\right.$ mean $=779.05 \mathrm{~km}^{2}$, range $=725.22-846.77 \mathrm{~km}^{2}$; Figure 7A $)$, the amount of savanna and pasture that occurred in the riparian 
zone increased dramatically. Because of the increase in savanna and pasture cover, the proportion of forest in the riparian zone declined from $51.9 \%$ in 1985 to $24.1 \%$ in 2018 (Figure 7B). The total area of the land-water interface increased with the opening of each dam, from $1,631.18 \mathrm{~km}^{2}$ in 1985 to $3,063.82 \mathrm{~km}^{2}$ in 2018. The land cover where the new reservoir shoreline is located is dominated by savanna and pasture rather than forest. Thus, savanna cover increases in the riparian zone with the opening of each dam (Figure 7). The largest change in riparian zone land cover occurred after the opening of the Serra da Mesa dam, which created a large reservoir bordered by savanna and pasture (Figure 7). However, it is clear land cover in the riparian zone is also changing not only from dam creation. This is best illustrated by the increase in pasture and declines in forest and especially savanna after the last dam was installed in 2011 (Figure 7).

Over time, the proportion of riparian land cover fronting lotic versus lentic water has also changed. Before any damming, 100\% of the riparian area fronted a lotic river (Figure 8). With the filling of the Serra da Mesa reservoir, this percentage decreased to approximately $60 \%$ lotic and $40 \%$ lentic. The opening of each subsequent dam led to a further increase in the proportion of lentic environment over the landscape (Figure 8). After the filling of the sixth reservoir, only $29 \%$ of the riparian vegetation surrounding the Tocantins River fronted lotic waters (Figure 8).

\section{Alluvial Forest}

Over the study period, alluvial forest decreased by $2.35 \mathrm{~km}^{2}$, less than $1 \%$ of the total area of the lotic river channel (Figure 9). From 1996 to 2007, forest cover increased by an average of $2.88 \mathrm{~km}^{2}$. This coincides with the filling of the first reservoir, which started in 1996. After the 2007 peak, alluvial forest declined steadily from 2007 until 2014, after which there was a slight increase. Alluvial forest during the study period ranged from 7.03 to $8.24 \%$ of the total river area.

\section{DISCUSSION}

The Tocantins River basin is a dynamic system impacted by extensive human alteration in the past few decades. Our results show this alteration has large impacts on critical riparian areas in the Tocantins basin. Two distinct processes are leading to land cover change in riparian areas: first, the installation of dams, leading to hydrologic change in the Tocantins River and surrounding riparian areas, and second, the conversion of natural ecosystems to pasture. Damming has indirect impacts on areas much larger than those deforested by the reservoir. In this system, we expect the area of indirect impacts of the installed dams to be at least one and a half times larger than the area impacted by reservoir creation. Environmental impact assessments (EIA) that ignore indirect impacts of dams will underestimate the biophysical effects of damming on riparian areas both upstream and downstream of the dams (Cochrane et al., 2017; Ritter et al., 2017). Deforestation rates in the lotic areas of our study region are higher than the $0.6 \%$ annual loss over the Brazilian Cerrado as a whole during a similar study period (1990-2010; Beuchle et al., 2015). Studies in the eastern Amazon similarly showed higher rates of deforestation in the riparian buffers set up by the Brazilian forest code than in surrounding upland forest (Nunes et al., 2019). These high rates of deforestation within the riparian buffer likely point to shortcomings with the Brazilian forest code (da Silva et al., 2017). Despite mandates to protect and restore riparian areas, these areas continue to be degraded and deforested.

The installation of dams led to an increase in the total amount of riparian area of the Tocantins River through the creation of reservoirs. However, as these new riparian zones have been pushed far from the original free-flowing river and are bordering lentic reservoirs, they are dominated by vegetation that may not be well-adapted to periodic flooding (de Oliveira et al., 2015; Pires et al., 2018). Development of riparian forest with species composition adapted to periodic flooding along reservoir margins may take decades or longer, or may never happen, due to the changed hydrology of the lentic environment compared to the lotic (Nilsson et al., 1997). Riparian vegetation surrounding lentic water may suffer stress from a higher water table, which could lead to floristic compositional changes and species mortality (Jin et al., 2019; dos Santos et al., 2020). Addition of newly created riparian zones around reservoirs and changes in flooding regime around reservoir areas can also lead to species invasions (Lesica and Miles, 1999; Nilsson and Berggren, 2000; Commander, 2013), further changing the composition of riparian vegetation in the region.
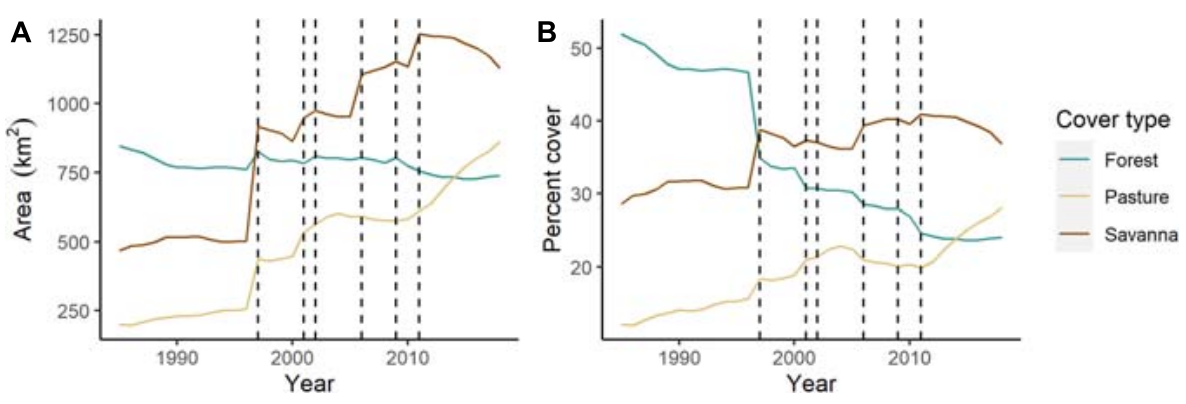

FIGURE 7 | (A) Total area $\left(\mathrm{km}^{2}\right)$ and (B) percent cover of forest, savanna, and pasture in the 0-500 $\mathrm{m}$ buffer surrounding the combined lotic and lentic areas of the Tocantins River. Dashed lines indicate the year a dam opened (in order: Serra da Mesa, Lajeado, Cana Brava, Peixe Angical, São Salvador, Estreito). 


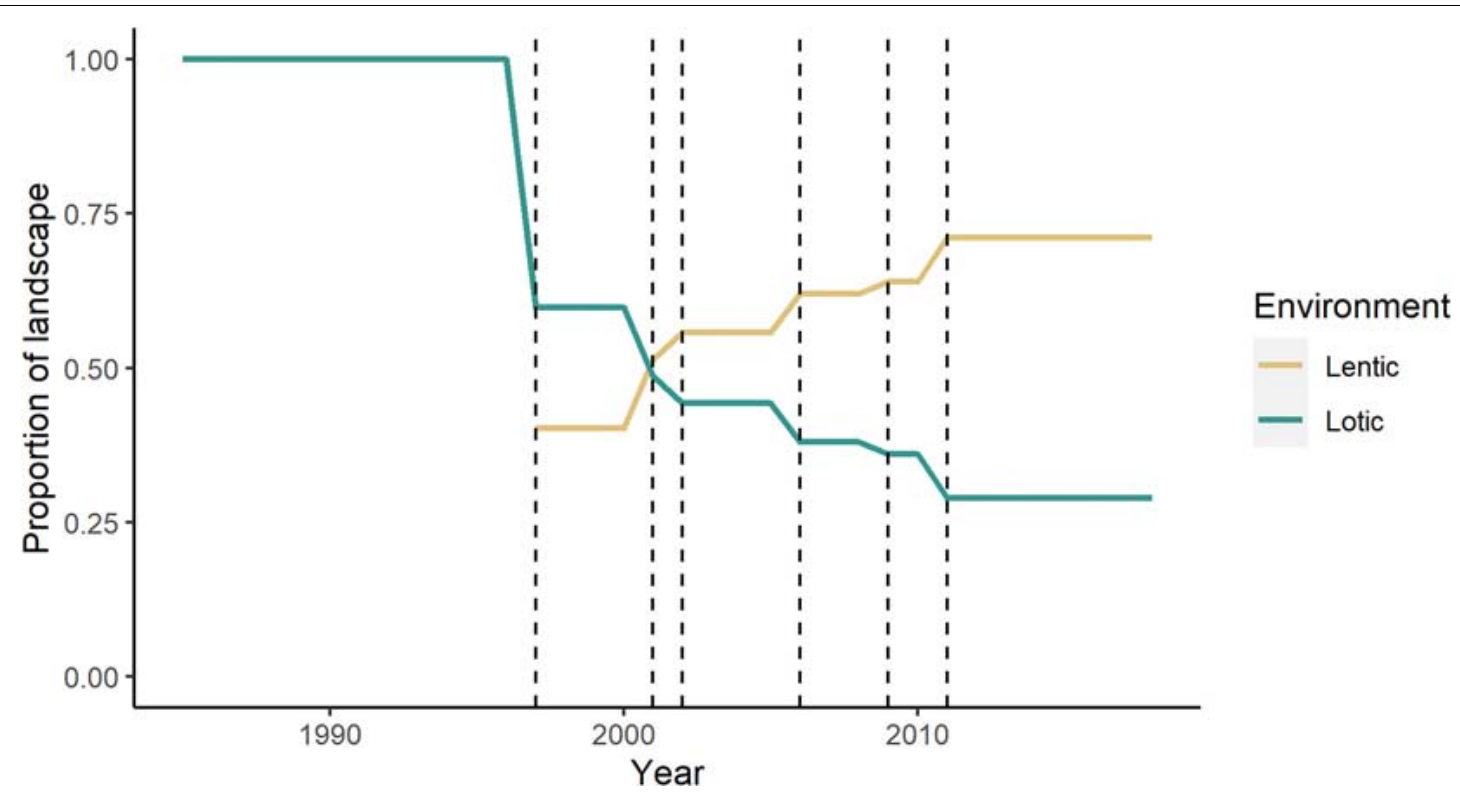

FIGURE 8 | Proportion of riparian vegetation fronting lotic versus lentic environments over the landscape. Dashed lines indicate the year each dam opened (in order: Serra da Mesa, Lajeado, Cana Brava, Peixe Angical, São Salvador, Estreito).

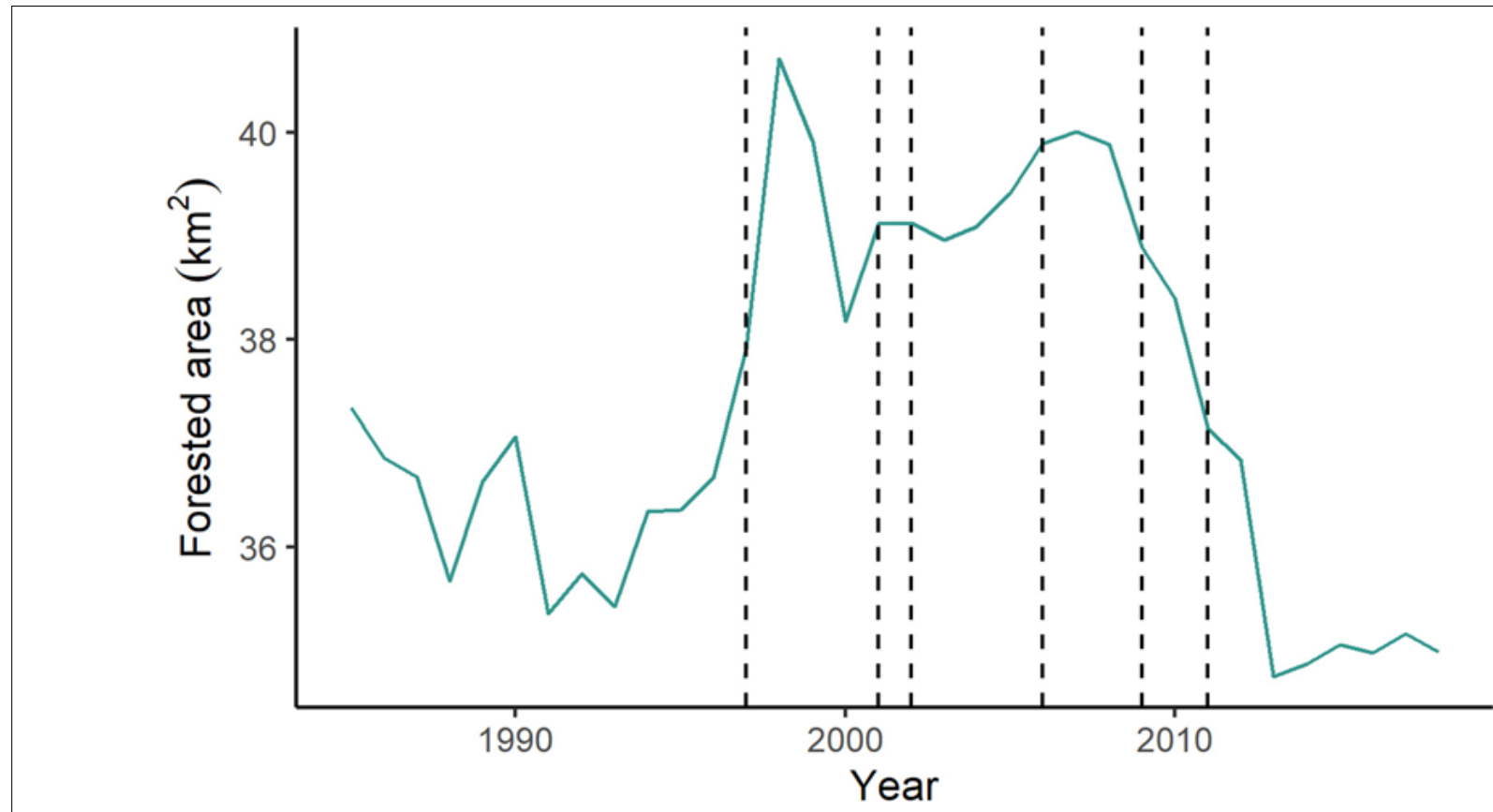

FIGURE 9 | Area of forest cover within the river channel over the study period (1985-2018). Dashed lines indicate the year a dam opened (in order: Serra da Mesa, Lajeado, Cana Brava, Peixe Angical, São Salvador, Estreito).

Downstream of the dams, riparian areas may experience smaller, shorter seasonal floods that are decoupled from the rainy season (Swanson et al., unpublished data). These changes in floodplain hydrology may affect the riparian vegetation downstream of dams, causing species that are highly specialized for regular, long-term flooding to be outcompeted by upland species (Latrubesse et al., 2020). Smaller floods may also disrupt seed dispersal via hydrochory or ichthyochory leading to changes in species composition in areas that no longer experience regular flooding (da Rocha et al., 2019). It is likely that in the longterm, riparian areas downstream of the dams in the Tocantins River may come to be dominated by savanna species and experience decline of forest due to decreases in seed dispersal and seedling establishment. 
Decreased flooding downstream of the dams may also have a synergistic relationship with land cover conversion to pasture. While Cerrado vegetation is fire adapted, the riparian vegetation of this region is not (Walter and Ribeiro, 2010). However, the main method of promoting grass regrowth for pasture is through the use of fire (Klink and Machado, 2005; Lúcio et al., 2014). As the riparian areas are no longer inundated, they may become more susceptible to fire due to accumulation of coarse woody debris (Ellis et al., 1999; Stromberg, 2001), which could lead to further degradation and conversion to pasture. Additionally, changes to the Brazilian forest code weakened protections for riparian buffers, making it so those riparian areas that have been degraded may not have to be reforested with native riparian species (Covre et al., 2015). This could further increase susceptibility to fire within riparian areas.

Additional pressures to deforest riparian lands may come from changes in fisheries or ability to practice subsistence agriculture. Installation of dams can lead to declines in abundance of commercially important fish (Hallwass et al., 2013), increases in overfishing (Doria et al., 2020), and reduced catch, especially of long-distance migratory species (Leite Lima et al., 2020). Irregular flooding can lead to abandoning subsistence floodplain agriculture, which can be used to supplement local diets (Laufer et al., 2020). Reduced flooding in riparian regions decreases soil fertility, which also diminishes the ability to practice floodplain agriculture or increases the cost due to the need purchase fertilizers (Laufer et al., 2020). Disruptions to income streams and food production may lead to increased deforestation in riparian regions to convert these areas to more profitable cattle pasture or for sale of hardwood.

Our results indicate the in-stream forest cover in the lotic portions of the Tocantins River is dynamic. A stable rise in in-stream vegetation started coincident with the filling of the Serra da Mesa reservoir. The alluvial vegetation remained higher throughout the study period until the opening of the São Salvador dam, the fifth on this stretch of the river. It is possible that the initial opening of the Serra da Mesa storage dam promoted formation of stable sand bars within the river, consistent with what has been observed after damming in some Asian rivers (Choi et al., 2005; Woo et al., 2010). However, the effects of damming on instream vegetation and island formation in the Tocantins River seem to be variable, suggesting the need for further study (Manyari and de Carvalho, 2007).

The riparian zone of the Cerrado plays an important role in providing various ecosystem services. Much of the landscape is being converted to agriculture, and these riparian zones act as buffers to reduce chemical outflows from agricultural fields into rivers (Nóbrega et al., 2020). The conservation of riparian forests in the Cerrado is also important for preserving terrestrial animal species abundance and diversity (Cabette et al., 2017; Paolino et al., 2018). Because of the ecosystem services provided for water quality, nutrient uptake, and biodiversity, as well as the intrinsic value of riparian habitats, it is important that they be conserved. The riparian zone of the Tocantins River is under increased pressure from both land cover change and hydrologic change from dams. However, there is evidence that restoration of riparian forest can be effective for preserving at least some ecosystem services these forests offer (Alcântara et al., 2004; Araujo et al., 2018).

\section{DATA AVAILABILITY STATEMENT}

The datasets presented in this study can be found in online repositories. The names of the repository/repositories and accession number(s) can be found below: https://zenodo.org/ record/4620082.

\section{AUTHOR CONTRIBUTIONS}

ACS contributed to the conceptualization, methodology, software, validation, formal analysis, investigation, resources, data curation, writing-original draft, writing-review and editing, visualization, project administration, and funding acquisition for this manuscript. SB contributed to conceptualization, methodology, resources, writing-review and editing, supervision, and funding acquisition. Both authors contributed to the article and approved the submitted version.

\section{FUNDING}

This research was funded in part by the Future Investigators in NASA Earth and Space Science and Technology award number 80 NSSC19K1355. ACS was also funded by the University of Florida Informatics Institute and University of Florida Water Institute Graduate Fellowship programs. This research is partially based upon work supported by the National Science Foundation (NSF) under Grant No. 1617413. Any opinions, findings, and conclusions or recommendations expressed in this article are those of the authors and do not necessarily reflect NSF views.

\section{ACKNOWLEDGMENTS}

We would like to thank the 2015 Water Institute Graduate Fellowship cohort as well as members of the Amazon Dams International Research Network for inspiring the questions behind this study. We also thank the reviewers whose suggestions improved this manuscript.

\section{SUPPLEMENTARY MATERIAL}

The Supplementary Material for this article can be found online at: https://www.frontiersin.org/articles/10.3389/fenvs.2021. 662904/full\#supplementary-material

Supplementary Figure 1 | Changes in composition of forest, savanna, and pasture in the Tocantins watershed, excluding the 0-500 $\mathrm{m}$ riparian buffer surrounding the Tocantins River and all reservoirs. 


\section{REFERENCES}

Akama, A. (2017). Impacts of the hydroelectric power generation over the fish fauna of the Tocantins River, Brazil: Marabá Dam, the final blow. Oecol. Aust. 21, 222-231. doi: 10.4257/oeco.2017.2103.01

Alcântara, F. A. D., Buurman, P., Curi, N., Neto, A. E. F., Van Lagen, B., and Meijer, E. L. (2004). Changes in soil organic matter composition after introduction of riparian vegetation on shores of hydroelectric reservoirs (Southeast of Brazil). Soil Biol. Biochem. 36, 1497-1508. doi: 10.1016/j.soilbio.2004.04.018

Alldredge, B., and Moore, G. (2014). Assessment of riparian vegetation sensitivity to river hydrology downstream of a major Texas dam. River Res. Appl. 30, 230-244. doi: 10.1002/rra.2625

Anderson, J. T., Rojas, J. S., and Flecker, A. S. (2009). High-quality seed dispersal by fruit-eating fishes in Amazonian floodplain habitats. Oecologia 161, 279-290. doi: 10.1007/s00442-009-1371-4

Arantes, C. C., Winemiller, K. O., Petrere, M., Castello, L., Hess, L. L., and Freitas, C. E. C. (2018). Relationships between forest cover and fish diversity in the Amazon river floodplain. J. Appl. Ecol. 55, 386-395. doi: 10.1111/1365-2664. 12967

Araujo, G. J., Fagundes, R., and Antonini, Y. (2018). Trap-nesting Hymenoptera and their network with parasites in recovered riparian forests Brazil. Neotrop. Entomol. 47, 26-36. doi: 10.1007/s13744-017-0504-4

Assahira, C., Piedade, M. T. F., Trumbore, S. E., Wittmann, F., Cintra, B. B. L., Batista, E. S., et al. (2017). Tree mortality of a flood-adapted species in response of hydrographic changes caused by an Amazonian river dam. For. Ecol. Manag. 396, 113-123. doi: 10.1016/j.foreco.2017.04.016

Beuchle, R., Grecchi, R. C., Shimabukuro, Y. E., Seliger, R., Eva, H. D., Sano, E., et al. (2015). Land cover changes in the Brazilian Cerrado and Caatinga biomes from 1990 to 2010 based on a systematic remote sensing sampling approach. Appl. Geogr. 58, 116-127. doi: 10.1016/j.apgeog.2015.01.017

Biggs, T. W., Santiago, T. M. O., Sills, E., and Caviglia-Harris, J. (2019). The Brazilian Forest Code and riparian preservation areas: spatiotemporal analysis and implications for hydrological ecosystem services. Reg. Environ. Chang. 19, 2381-2394. doi: 10.1007/s10113-019-01549-w

Bruijnzeel, L. A. (2004). Hydrological functions of tropical forests: not seeing the soil for the trees? Agric. Ecosyst. Environ. 10401, 185-228. doi: 10.1016/j.agee. 2004.01.015

Budke, J. C., Jarenkow, J. A., and de Oliveira-Filho, A. T. (2010). Intermediary disturbance increases tree diversity in riverine forest of southern Brazil. Biodivers. Conserv. 19, 2371-2387. doi: 10.1007/s10531-010-9845-6

Cabette, H. S. R., Souza, J. R., Shimano, Y., and Juen, L. (2017). Effects of changes in the riparian forest on the butterfly community (Insecta: Lepidoptera) in Cerrado areas. Rev. Bras. Entomol. 61, 43-50. doi: 10.1016/j.rbe.2016.10.004

Choi, S.-U., Yoon, B., and Woo, H. (2005). Effects of dam-induced flow regime change on downstream river morphology and vegetation cover in the Hwang river, Korea. River Res. Appl. 21, 315-325. doi: 10.1002/rra.849

Clerici, N., Paracchini, M. L., and Maes, J. (2014). Land-cover change dynamics and insights into ecosystem services in European stream riparian zones. Ecohydrol. Hydrobiol. 14, 107-120. doi: 10.1016/j.ecohyd.2014.01.002

Cochrane, S. M. V., Matricardi, E. A. T., Numata, I., and Lefebvre, P. A. (2017). Landsat-based analysis of mega dam flooding impacts in the Amazon compared to associated environmental impact assessments: upper Madeira river example 2006-2015. Remote Sens. Appl. Soc. Environ. 7, 1-8. doi: 10.1016/j.rsase.2017. 04.005

Commander, C. (2013). The Influence of Dams on the Abundance of Arundo donax (Giant Reed) in Riparian Corridors. Available online at: http://dspace.calstate. edu/handle/10211.9/2335 (accessed October 23, 2020).

Costa, M. H., Botta, A., and Cardille, J. A. (2003). Effects of large-scale changes in land cover on the discharge of the Tocantins river, Southeastern Amazonia. J. Hydrol. 283, 206-217. doi: 10.1016/S0022-1694(03)00267-1

Covre, J., Clemente, F., and Lirio, V. S. (2015). "New Brazilian forest code: changes and prospects," in Proceedings of the 2015 Conference, August 9-14, 2015, Milan (Milan: International Association of Agricultural Economists). doi: 10.22004/ ag.econ. 212768

da Rocha, M., de Assis, R. L., Piedade, M. T. F., Feitosa, Y. O., Householder, J. E., Lobo, G., et al. (2019). Thirty years after Balbina dam: diversity and floristic composition of the downstream floodplain forest, central Amazon, Brazil. Ecohydrology 12:e2144. doi: 10.1002/eco.2144 da Silva, N. M., Angeoletto, F., Santos, J. W. M. C., Paranhos Filho, A. C., Vacchiano, M. C., Bohrer, J. F. C., et al. (2017). The negative influences of the new Brazilian forest code on the conservation of riparian forests. Eur. J. Ecol. 3, 116-122. doi: 10.1515/eje-2017-0019

de Oliveira, A. S., Ferreira, C. S., Graciano-Ribeiro, D., and Franco, A. C. (2015). Anatomical and morphological modifications in response to flooding by six Cerrado tree species. Acta Bot. Brasilica 29, 478-488. doi: 10.1590/010233062014 abb0035

de Oliveira, N. M. (2015). Desenvolvimento Regional do Território do Estado do Tocantins: Implicações e Alternativas. Ph.D. thesis. Cascavel: Universidade Estadual do Oeste do Paraná.

De Simone, O., Müller, E., Junk, W. J., and Schmidt, W. (2002). Adaptations of central Amazon tree species to prolonged flooding: root morphology and leaf longevity. Plant Biol. 4, 515-522. doi: 10.1055/s-2002-34127

de Souza, A. L. T. D., Fonseca, D. G., Libório, R. A., and Tanaka, M. O. (2013). Influence of riparian vegetation and forest structure on the water quality of rural low-order streams in SE brazil. For. Ecol. Manag. 298, 12-18. doi: 10.1016/ j.foreco.2013.02.022

Doria, C. R. C., Dutka-Gianelli, J., Brasil de Sousa, S. T., Chu, J., and Garlock, T. M. (2020). Understanding impacts of dams on the small-scale fisheries of the Madeira river through the lens of the fisheries performance indicators. Mar. Policy 125:104261. doi: 10.1016/j.marpol.2020.104261

dos Santos, E. A., Medeiros, M. B., Ferreira, E. J. L., Simon, M. F., Oliveira, W. L., and Costa, F. R. C. (2020). Palm distribution patterns in the southwestern Brazilian Amazon: impact of a large hydroelectric dam. For. Ecol. Manag. 463:118032. doi: 10.1016/j.foreco.2020.118032

Ellis, L. M., Molles, M. C., and Crawford, C. S. (1999). Influence of experimental flooding on litter dynamics in a rio grande riparian forest, New Mexico. Restor. Ecol. 7, 193-204. doi: 10.1046/j.1526-100X.1999.72012.x

Fernández, D., Barquín, J., Álvarez-Cabria, M., and Peñas, F. J. (2014). Landuse coverage as an indicator of riparian quality. Ecol. Indic. 41, 165-174. doi: 10.1016/j.ecolind.2014.02.008

Ferreira, L. V., Cunha, D. A., Chaves, P. P., Matos, D. C. L., and Parolin, P. (2013). Impacts of hydroelectric dams on alluvial riparian plant communities in eastern Brazilian Amazonian. An. Acad. Bras. Cienc. 85, 1013-1023. doi: 10.1590/S0001-37652013000300012

Hallwass, G., Lopes, P. F., Juras, A. A., and Silvano, R. A. M. (2013). Fishers' knowledge identifies environmental changes and fish abundance trends in impounded tropical rivers. Ecol. Appl. 23, 392-407. doi: 10.1890/12-0429.1

Helfenstein, J., and Kienast, F. (2014). Ecosystem service state and trends at the regional to national level: a rapid assessment. Ecol. Indic. 36, 11-18. doi: 10. 1016/j.ecolind.2013.06.031

Hiraoka, M. (1985). Floodplain farming in the Peruvian Amazon. Geogr. Rev. Japan Ser. B. 58, 1-23. doi: $10.4157 /$ grj1984b.58.1

IBGE (2020). Tocantins. Available Online at: https://www.ibge.gov.br/cidades-eestados/to/ (accessed October 7, 2020).

Jin, Z., Guo, L., Wang, Y., Yu, Y., Lin, H., Chen, Y., et al. (2019). Valley reshaping and damming induce water table rise and soil salinization on the Chinese loess plateau. Geoderma 339, 115-125. doi: 10.1016/j.geoderma.2018.12.048

Joly, C. A. (2010). The changes proposed in the Brazilian Forest Code do not have scientific support. Biota Neotrop. 10:4.

Jones, K. B., Slonecker, E. T., Nash, M. S., Neale, A. C., Wade, T. G., and Hamann, S. (2010). Riparian habitat changes across the continental United States (19722003) and potential implications for sustaining ecosystem services. Landsc. Ecol. 25, 1261-1275. doi: 10.1007/s10980-010-9510-1

Junk, W. J., Bayley, P. B., and Sparks, R. E. (1989). The flood pulse concept in river-floodplain systems. Can. Spec. Publ. Fish. Aquat. Sci. 106, 110-127.

Junk, W. J. (ed.) (2010). Amazonian Floodplain Forests: Ecophysiology, Biodiversity and Sustainable Management. Dordrecht [Netherlands]?. New York, NY: Springer. doi: 10.1007/978-90-481-8725-6

Keesstra, S. D., Kondrlova, E., Czajka, A., Seeger, M., and Maroulis, J. (2012). Assessing riparian zone impacts on water and sediment movement: a new approach. Geol. Mijnbouw Netherlands J. Geosci. 91, 245-255. doi: 10.1017/ s0016774600001633

Klink, C. A., and Machado, R. B. (2005). Conservation of the Brazilian Cerrado. Conserv. Biol. 19, 707-713. doi: 10.1111/j.1523-1739.2005.00702.x

Kubitzki, K., and Ziburski, A. (1994). Seed dispersal in flood plain forests of Amazonia. Biotropica 26:30. doi: 10.2307/2389108 
Latrubesse, E. M., d'Horta, F. M., Ribas, C. C., Wittmann, F., Zuanon, J., Park, E., et al. (2020). Vulnerability of the biota in riverine and seasonally flooded habitats to damming of Amazonian rivers. Aquat. Conserv. Mar. Freshw. Ecosyst. Aqc. 3424, 1-14. doi: 10.1002/aqc.3424

Laufer, J., Marques, E. E., Athayde, S., Swanson, A. C., and Zagallo, A. D. A. (eds). (2020). Rios, Terras e Culturas: Aprendendo Com o Sistema Socioecológico do Tocantins. Porto Alegre: Editora Fi. doi: 10.22350/9786587340197

Ledo, R. M. D., and Colli, G. R. (2016). Silent death: the new Brazilian Forest Code does not protect lizard assemblages in Cerrado riparian forests. South Am. J. Herpetol. 11, 98-109.

Lees, A. C., Peres, C. A., Fearnside, P. M., Schneider, M., and Zuanon, J. A. S. (2016), Hydropower and the future of Amazonian biodiversity. Biodivers. Conserv. 25, 451-466. doi: 10.1007/s10531-016-1072-3

Leite Lima, M. A., Rosa Carvalho, A., Alexandre Nunes, M., Angelini, R., and Rodrigues da Costa Doria, C. (2020). Declining fisheries and increasing prices: the economic cost of tropical rivers impoundment. Fish. Res. 221:105399. doi: 10.1016/j.fishres.2019.105399

Lesica, P., and Miles, S. (1999). Russian olive invasion into cottonwood forests along a regulated river in north-central Montana. Can. J. Bot. 77, 1077-1083. doi: 10.1139/b99-088

de Lobo, G. S., Wittmann, F., and Piedade, M. T. F. (2019). Response of black-water floodplain (igapó) forests to flood pulse regulation in a dammed Amazonian river. For. Ecol. Manag. 434, 110-118.

Lobón-Cerviá, J., Hess, L. L., Melack, J. M., and Araujo-Lima, C. A. R. M. (2015). The importance of forest cover for fish richness and abundance on the Amazon floodplain. Hydrobiologia 750, 245-255. doi: 10.1007/s10750-014-2040-0

Lúcio, S. L. B., Pereira, L. E. C., and Ludewigs, T. (2014). O gado que circulava: desafios da gestão participativa de unidades de conservação nos gerais do norte de Minas. Biodivers. Bras 4, 130-156.

Mallik, A. U., and Richardson, J. S. (2009). Riparian vegetation change in upstream and downstream reaches of three temperate rivers dammed for hydroelectric generation in British Columbia, Canada. Ecol. Eng. 35, 810-819. doi: 10.1016/j. ecoleng.2008.12.005

Manyari, W. V., and de Carvalho, O. A. (2007). Environmental considerations in energy planning for the Amazon region: downstream effects of dams. Energy Policy 35, 6526-6534. doi: 10.1016/j.enpol.2007.07.031

Myers, N., Mittermeier, R. A., Mittermeier, C. G., Da Fonseca, G. A. B., and Kent, J. (2000). Biodiversity hotspots for conservation priorities. Nature 403, 853-858. doi: $10.1038 / 35002501$

Naiman, R. J., Decamps, H., and Pollock, M. (1993). The role of riparian corridors in maintaining regional biodiversity. Ecol. Appl. 3, 209-212. doi: 10.2307/ 1941822

National Research Council (2002). Riparian Areas. Washington, DC: National Academies Press. doi: 10.17226/10327

Newbold, J. D., Herbert, S., Sweeney, B. W., Kiry, P., and Alberts, S. J. (2010). Water quality functions of a 15-year-old riparian forest buffer system. Am. Water Resour. Assoc. 46, 299-310. doi: 10.1111/j.1752-1688.2010.00421.x

Nilsson, C., and Berggren, K. (2000). Alterations of riparian ecosystems caused by river regulation. Bioscience 50, 783-792.

Nilsson, C., and Dynesius, M. (1994). Ecological effects of river regulation on mammals and birds: a review. Regul. Rivers Res. Manag. 9, 45-53. doi: 10.1002/ rrr.3450090105

Nilsson, C., Jansson, R., and Zinko, U. (1997). Long-term responses of river-margin vegetation to water-level regulation. Science 276, 798-800. doi: 10.1126/science. 276.5313 .798

Nóbrega, R. L. B., Ziembowicz, T., Torres, G. N., Guzha, A. C., Amorim, R. S. S., Cardoso, D., et al. (2020). Ecosystem services of a functionally diverse riparian zone in the Amazon-Cerrado agricultural frontier. Glob. Ecol. Conserv. 21:e00819. doi: 10.1016/j.gecco.2019.e00819

Nunes, S., Barlow, J., Gardner, T., Sales, M., Monteiro, D., and Souza, C. (2019). Uncertainties in assessing the extent and legal compliance status of riparian forests in the eastern Brazilian Amazon. Land Use Policy 82, 37-47. doi: 10. 1016/j.landusepol.2018.11.051

Oliveira-Filho, A. T., and Ratter, J. A. (2002). "Vegetation physiognomies and woody flora of the cerrado biome," in The Cerrados of Brazil: Ecology and Natural History of a Neotropical Savanna, eds P. S. Oliveira and R. J. Marquis (New York, NY: Columbia University Press), 91-120.
Paolino, R. M., Royle, J. A., Versiani, N. F., Rodrigues, T. F., Pasqualotto, N., Krepschi, V. G., et al. (2018). Importance of riparian forest corridors for the ocelot in agricultural landscapes. J. Mammal. 99, 874-884. doi: 10.1093/ jmammal/gyy075

Parolin, P. (2012). Diversity of adaptations to flooding in trees of Amazonian floodplains. Pesqui. Bot. 63, 7-28.

Parolin, P., De Simone, O., Haase, K., Waldhoff, D., Rottenberger, S., Kuhn, U., et al. (2004). Central amazonian floodplain forests: tree adaptations in a pulsing system. Bot. Rev. 70, 357-380.

Parolin, P., and Wittmann, F. (2010). Struggle in the flood: tree responses to flooding stress in four tropical floodplain systems. AoB Plants 2010:plq003. doi: $10.1093 /$ aobpla/plq003

Pires, H. R. A., Franco, A. C., Piedade, M. T. F., Scudeller, V. V., Kruijt, B., and Ferreira, C. S. (2018). Flood tolerance in two tree species that inhabit both the Amazonian floodplain and the dry Cerrado savanna of Brazil. AoB Plants 10:ply065. doi: 10.1093/aobpla/ply065

Puyravaud, J. P. (2003). Standardizing the calculation of the annual rate of deforestation. For. Ecol. Manag. 177, 593-596. doi: 10.1016/S0378-1127(02) 00335-3

R Core Team (2020). R: A Language and Environment for Statistical Computing. Available online at: https://www.r-project.org/ (accessed October 1, 2020).

Ratter, J. A., Ribeiro, J. F., and Bridgewater, S. (1997). The Brazilian Cerrado vegetation and threats to its biodiversity. Ann. Bot. 80, 223-230. doi: 10.1006/ anbo.1997.0469

Resende, A. F., de Schöngart, J., Streher, A. S., Ferreira-Ferreira, J., Piedade, M. T. F., and Silva, T. S. F. (2019). Massive tree mortality from flood pulse disturbances in Amazonian floodplain forests: the collateral effects of hydropower production. Sci. Total Environ. 659, 587-598. doi: 10.1016/j. scitotenv.2018.12.208

Resende, A. F., Piedade, M. T. F., Feitosa, Y. O., Andrade, V. H. F., Trumbore, S. E., Durgante, F. M., et al. (2020). Flood-pulse disturbances as a threat for long-living Amazonian trees. New Phytol. 227, 1790-1803. doi: 10.1111/nph. 16665

Ribeiro, J. F., and Walter, B. M. T. (1998). "Fitofisionomias do bioma Cerrado," in Cerrado: Ambiente e Flora, eds S. M. Sano and S. P. de Almeida (Planaltina: Embrapa-CPAC).

Rieger, I., Lang, F., Kowarik, I., and Cierjacks, A. (2014). The interplay of sedimentation and carbon accretion in riparian forests. Geomorphology 214, 157-167. doi: 10.1016/j.geomorph.2014.01.023

Ritter, C. D., McCrate, G., Nilsson, R. H., Fearnside, P. M., Palme, U., and Antonelli, A. (2017). Environmental impact assessment in Brazilian Amazonia: challenges and prospects to assess biodiversity. Biol. Conserv. 206, 161-168. doi: 10.1016/j. biocon.2016.12.031

Rocha, M., Assis, R. L., Piedade, M. T. F., Feitosa, Y. O., Householder, J. E., Lobo, G., et al. (2019). Thirty years after Balbina Dam: diversity and floristic composition of the downstream floodplain forest, central Amazon, Brazil. Ecohydrology 12:e2144.

Souza, C. M., Shimbo, J. Z., Rosa, M. R., Parente, L. L., Alencar, A. A., Rudorff, B. F. T., et al. (2020). Reconstructing three decades of land use and land cover changes in Brazilian biomes with landsat archive and earth engine. Remote Sens. 12:2735. doi: 10.3390/RS12172735

Stromberg, J. C. (2001). Restoration of riparian vegetation in the south-western United States: importance of flow regimes and fluvial dynamism. J. Arid Environ. 49, 17-34. doi: 10.1006/jare.2001.0833

Surasinghe, T. D., and Baldwin, R. F. (2015). Importance of riparian forest buffers in conservation of stream biodiversity: responses to land uses by stream-associated salamanders across two southeastern temperate ecoregions. J. Herpetol. 49, 83-94. doi: 10.1670/14-003

Thomas, D. H. L. (1996). Dam construction and ecological change in the riparian forest of the Hadejia-Jama'are floodplain, Nigeria. L. Degrad. Dev. 7, 279-295. doi: 10.1002/(SICI)1099-145X(199612)7:4<279::AID-LDR234<3.0.CO;2-L

Todd, M., and Elmore, W. (1997). "Historical changes in western riparian ecosystems," in Proceedings of the North American Wildlife and Natural Resources Conference (USA), Washington, D.C.

Trancoso, R., Carneiro Filho, A., Tomasella, J., Schietti, J., Forsberg, B. R., and Miller, R. P. (2009). Deforestation and conservation in major watersheds of the Brazilian Amazon. Environ. Conserv. 36, 277-288. doi: 10.1017/ S0376892909990373 
Treuhaft, R. N., Chapman, B. D., Dos Santos, J. R., Gonçalves, F. G., Dutra, L. V., Graça, P. M. L. A., et al. (2009). Vegetation profiles in tropical forests from multibaseline interferometric synthetic aperture radar, field, and lidar measurements. J. Geophys. Res. Atmos. 114, 1-16. doi: 10.1029/2008JD011674

Valera, C. A., Pissarra, T. C. T., Valle Júnior, R. F., do Oliveira, C. F., Moura, J. P., Sanches Fernandes, L. F., et al. (2019). The buffer capacity of riparian vegetation to control water quality in anthropogenic catchments from a legally protected area: a critical view over the Brazilian new forest code. Water 11:549. doi: 10.3390/w11030549

Walter, B. M. T., and Ribeiro, J. F. (2010). "Diversidade fitofisionômica e o papel do fogo no bioma Cerrado," in Efeitos do Regime de Fogo Sobre a Estrutura de Comunidades de Cerrado: Projeto Fogo, ed. H. S. Miranda (Brasilía: IBAMA), 59-76.

Wittmann, F., Schöngart, J., and Junk, W. J. (2010). "Phytogeography, species diversity, community structure and dynamics of central Amazonian floodplain forests," in Amazonian Floodplain Forests, eds W. Junk, M. Piedade, F. Wittmann, J. Schöngart, and P. Parolin (Dordrecht: Springer), 61-102. doi: 10.1007/978-90-481-8725-6_4

Wittmann, F., Zorzi, B. T., Tizianel, F. A. T., Urquiza, M. V. S., Faria, R. R., e Sousa, N. M., et al. (2008). Tree species composition, structure, and aboveground wood biomass of a riparian forest of the lower Miranda River, Southern Pantanal, Brazil. Folia Geobot 43, 397-411. doi: 10.1007/s12224-008-9022-9

Woo, H.-S., Park, M.-H., Cho, K.-H., Cho, H.-J., and Chung, S.-J. (2010). Recruitment and uccession of riparian vegetation in alluvial river regulated by upstream dams - focused on the Nakdong river downstream Andong and Imha dams. J. Korea Water Resour. Assoc. 43, 455-469. doi: 10.3741/jkwra.2010.43.5. 455

Wynn, T. M., Mostaghimi, S., and Alphin, E. F. (2004). “The effects of vegetation on stream bank erosion," in Proceedings of the 2004 ASAE Annual Meeting (Ottawa, ON: American Society of Agricultural and Biological Engineers), 1.

Yang, S., Bai, J., Zhao, C., Lou, H., Zhang, C., Guan, Y., et al. (2018). The assessment of the changes of biomass and riparian buffer width in the terminal reservoir under the impact of the south-to-north water diversion project in China. Ecol. Indic. 85, 932-943. doi: 10.1016/j.ecolind.2017.11.011

Zomer, R. J., Ustin, S. L., and Carpenter, C. C. (2001). Land cover change along tropical and subtropical riparian corridors within the Makalu Barun national park and conservation area, Nepal. Mt. Res. Dev. 21, 175-183.

Conflict of Interest: The authors declare that the research was conducted in the absence of any commercial or financial relationships that could be construed as a potential conflict of interest.

Copyright (c) 2021 Swanson and Bohlman. This is an open-access article distributed under the terms of the Creative Commons Attribution License (CC BY). The use, distribution or reproduction in other forums is permitted, provided the original author(s) and the copyright owner(s) are credited and that the original publication in this journal is cited, in accordance with accepted academic practice. No use, distribution or reproduction is permitted which does not comply with these terms. 